\title{
Obtaining a second opinion is a neglected source of health care inequalities
}

\author{
Jochanan BenbassatiD
}

\begin{abstract}
Observational studies have detected discrepancies between two expert interpreters of imaging and histopathological studies. Furthermore, in a substantial proportion of patients, an independent second opinion disagreed with the first one. Therefore, it is widely accepted that patients have a right to obtain a second opinion and, in case of divergent opinions, to deliberate and choose the option that they believe is most consistent with their individual circumstances. However, doctors are less likely to inform old and poorly educated patients about the possibility of seeking a second opinion, and this may contribute to healthcare inequalities. Hence the importance of (a) promoting doctors' self-awareness of a possible tendency to discriminate against old and poorly educated patients, and (b) creating programs within the healthcare system that would help patients in seeking a second opinion, suggest specialists for the specific problem of the patient, and provide tools to reconcile between discrepant opinions.
\end{abstract}

Keywords: Second opinion, Health seeking behaviors, Health policy, Doctor-patient communication

Yerushalmy [1] is credited for being the first to report that a competent radiologist misses as many as $32 \%$ of the lesions on a single chest $\mathrm{x}$-ray reading and disagrees with himself in about one-fifth of two readings of the same $x$-ray. Since then, there have been repeated reports of discrepancies in the interpretations of imaging and histopathological studies, as well as between clinical assessments. As late as 2015-2018, discrepancies between two expert interpreters have been reported in $22-57 \%$ of imaging studies [2-10] and in 25-37\% of histopathology studies [11-14]. Discrepancies between clinical assessments have been reported in $20 \%$ of the cases of breast cancer [15], in 35\% of patients in whom spinal surgery was recommended [16], and in 20 to $38 \%$ of patients with pancreatic cancer [17].

Therefore, Yerushalmy's recommendation in the 1950s that dual reading may contribute to radiography is appropriate also for the 2010s and not only for radiography. Today, it is widely agreed that, unless it may delay a life-saving intervention, patients have a right to an independent second opinion [18], and that second opinions may lower health care costs while reducing

Correspondence: benbasat@jdc.org.il

Myers-JDC-Brookdale Institute, Department of Health Policy Research, PO Box 3886, 91037 Jerusalem, Israel

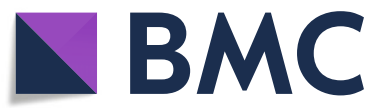

(c) The Author(s). 2019 Open Access This article is distributed under the terms of the Creative Commons Attribution 4.0 International License (http://creativecommons.org/licenses/by/4.0/), which permits unrestricted use, distribution, and

reproduction in any medium, provided you give appropriate credit to the original author(s) and the source, provide a link to the Creative Commons license, and indicate if changes were made. The Creative Commons Public Domain Dedication waiver (http://creativecommons.org/publicdomain/zero/1.0/) applies to the data made available in this article, unless otherwise stated. both over-and under-treatment [19]. Several authors have recommended creating programs within the healthcare system that would help patients in seeking a second opinion, suggest specialists for the specific problem of the patient, and provide tools to reconcile discrepant opinions [20]. However, as of now such programs are rare, and obtaining a second opinion is mostly initiated by patients.

In their 2017 paper in the IJHPR, Shmueli et al. [21] join the recommendation to encourage patients to seek a second opinion. The authors surveyed a representative sample of the Israeli population and found that $41 \%$ had sought a second opinion because of doubts about diagnosis or treatment (38\%), search for a sub-specialty expert (19\%) and dissatisfaction with the first opinion (19\%). As many as 56\% reported a difference between the two opinions and $91 \%$ of them preferred the second.

These findings are consistent with those reported by others. Systematic reviews of the literature have indicated that the quest for a second opinion in different patient populations varied widely between 7 and 36\% [20] and between 1 and 88\% [22]. Patients sought a second opinion in order to confirm a diagnosis or treatment, or obtain information about persistent symptoms or treatment complications [22-24]. Systematic reviews 
have also indicated that the second opinion confirmed the original diagnosis or treatment in $43-82 \%$ of cases [20], and yielded a change in the diagnosis, treatment, or prognosis in $12-69 \%$ [20], 10-62\% [23] and 2-51\% [22]. Of particular interest were the outcomes of a program (Best Doctors, Inc.) that allows employee-beneficiaries to request free second opinion and to have trained physicians summarize the cases, identify unresolved clinical questions, and forward the cases to specialists for independent assessments and recommendations. It was found that a second opinion resulted in changes in diagnosis (15\%), treatment (37\%), or both (11\%). The clinical impact of a second opinion was estimated as moderate / major in $21 \%$ of cases for diagnosis and 31\% of cases for treatment. Most patients (95\%) were satisfied with the experience, but fewer (61\%) planned to follow the recommendations [24].

In summary, the main finding of these surveys was that a second opinion disagreed with the first one in a substantial proportion of patients [20-23]. The main limitation of these surveys is the absence of a gold standard that would identify "correct" opinions. Still, it is widely agreed that patients have a right to an independent second opinion and, in case of divergent opinions, to deliberate and choose the option that they believe is most consistent with their individual preferences.

Where should we go from here? I believe that further surveys aimed at determining the proportion of patients seeking a second opinion and their reasons for doing that are not warranted. However, the findings that patients with lower socioeconomic status and education were less likely to seek a second opinion $[22,25,26]$ and that physicians were more likely to inform young and educated patients about the possibility of seeking it [27] are highly disturbing. These findings identify an additional source of health care inequalities.

One could envisage administrative interventions that would reduce these inequalities. For example, the ministry of health or individual health plans could include the procurement of a second opinion into the charter of patients' rights and prominently display these rights in outpatient facilities. The ministry of health may assign to family doctors the responsibility for encouraging patients with chronic disorders, cancer and those who consider surgical or risky diagnostic / treatment intervention to seek a second opinion. Finally, health plans may disseminate the information that differences of opinion are common and provide instructions that would help both patients and their family doctors in finding specialists for specific problems. Still, I feel that administrative interventions will be only partially effective if not supplemented by doctors' awareness and cooperation.

Some doctors admit having negative feelings about certain patients. However, only few are aware that these feelings may lead to a subconscious discrimination against elderly [28] and poor [29] patients. Doctors should be reminded of the undisputed association between all-cause mortality and socioeconomic status (income, education) [30, 31]. In other words, poor, uneducated and older patients are more susceptible to disease. Any symptom or sign in a poor, elderly, or uneducated person may herald a more serious disease than in patients without these risk indicators, just as the probability of a life-threatening infection in a neutropenic patient with fever is higher than that in a non-neutropenic person with the same degree of fever. Hopefully, doctors' awareness that poverty, lower education and old age are risk indicators for disease will reduce their subconscious discrimination against such patients.

Second, doctors should be aware of the main barriers that prevent patients from seeking a second opinion. Focus groups have indicated that these barriers are patients' sense of shock, pressure of time, information overload, and fear of jeopardizing the patient-physician relationship [32]. Therefore, an appropriate delivery of "bad news" would include an unhurried consultation, patient's encouragement to seek a second opinion, and scheduling a follow-up visit in order to respond to additional patient's questions, provide additional information and gain an insight into the patient's understanding of his / her disease.

Third, doctors should help patients cope with divergent first and second opinions. Evidence suggests that a major drive to seek a second opinion is patient's dissatisfaction with the first one. In-depth patients' interviews indicated that they wanted the consultant to apply his/ her knowledge to the specifics of their individual cases, and were disappointed and distrustful when physicians cited only general prognostic statistics [33]. Both family doctors and consultants can gain an insight into the specifics of the patient's individual case by asking questions such as "it would help me advise you if you told me what you think about your disease" or "what worries you most about your disease" or "what do you want most to avoid" or "what do you expect from the treatment".

\section{Acknowledgements \\ None. \\ Funding \\ None.}

Availability of data and materials Not Applicable.

Author's contributions

The author read and approved the final manuscript.

Authors' information

Jochanan Benbassat was a staff physician at the department of Medicine at the Hadassah University Hospital between 1962 and 1992, and since 1983, Professor of Medicine and chair of Medical Education at the Hebrew University in Jerusalem. In 1992-1997, he was head of the department of 
Sociology of Health and chair of Behavioral Sciences in Medicine at the Faculty of Health Sciences in Beer-Sheva. Since 1998, he is a research associate at the Health Policy Research Program of the JDC Meyers-Brookdale Institute.

\section{Ethics approval and consent to participate}

Not Applicable.

\section{Consent for publication}

Not Applicable.

\section{Competing interests}

The author declares that he/she has no competing interests.

\section{Publisher's Note}

Springer Nature remains neutral with regard to jurisdictional claims in published maps and institutional affiliations.

Received: 6 January 2019 Accepted: 10 January 2019

Published online: 16 January 2019

\section{References}

1. Yerushalmy J. Reliability of chest radiography in the diagnosis of pulmonary lesions. Am J Surg. 1955;89:231-40.

2. Wibmer A, Vargas HA, Donahue TF, Zheng J, Moskowitz C, Eastham J, Sala E, Hricak H. Diagnosis of extracapsular extension of prostate Cancer on prostate MRI: impact of second-opinion readings by subspecialized genitourinary oncologic radiologists. AJR Am J Roentgenol. 2015;205:W73-8.

3. Chalian M, Del Grande F, Thakkar RS, Jalali SF, Chhabra A, Carrino JA. Second-opinion subspecialty consultations in musculoskeletal radiology. AJR Am J Roentgenol. 2016;206:1217-21.

4. Hansen NL, Koo BC, Gallagher FA, Warren AY, Doble A, Gnanapragasam V, Bratt O, Kastner C, Barrett T. Comparison of initial and tertiary Centre second opinion reads of multi-parametric magnetic resonance imaging of the prostate prior to repeat biopsy. Eur Radiol. 2017;27:2259-66.

5. Sawan P, Rebeiz K, Schoder H, Batlevi C, Moskowitz A, Ulaner GA, Dunphy M, Mannelli L. Specialized second-opinion radiology review of PET/CT examinations for patients with diffuse large B-cell lymphoma impacts patient care and management. Medicine (Baltimore). 2017;96:e9411.

6. Strogus K, Roedl JB, Morrison WB, Zoga AC. Clinical impact of second-opinion musculoskeletal subspecialty interpretations during a multidisciplinary orthopedic oncology conference. J Am Coll Radiol. 2017;14:931-6.

7. Chang Sen LQ, Mayo RC, Lesslie MD, Yang WT, Leung JWT. Impact of second-opinion interpretation of breast imaging studies in patients not currently diagnosed with breast Cancer. J Am Coll Radiol. 2018;15:980-7.

8. Weinfurtner RJ, Niell B, Mekhail Y, Aguila E, Kamat L. Specialized second opinion interpretations of breast imaging: impact on additional workup and management. Clin Breast Cancer. 2018;18:e1031-6.

9. Shetty AS, Mittal A, Salter A, Narra VR, Fowler KJ. Hepatopancreaticobiliary imaging second-opinion consultations: is there value in the second Reading? AJR Am J Roentgenol. 2018;211:1264-72.

10. Alves I, Cunha TM. Clinical importance of second-opinion interpretations by radiologists specializing in gynecologic oncology at a tertiary cancer center: magnetic resonance imaging for endometrial cancer staging. Radiol Bras. 2018;51:26-31

11. Marco V, Muntal T, GarcÃa-Hernandez F, Cortes J, Gonzalez B, Rubio IT. Changes in breast cancer reports after pathology second opinion. Breast J. 2014;20:295-301.

12. Luchey AM, Manimala NJ, Dickinson S, Dhillon J, Agarwal G, Lockhart J Spiess PE, Sexton WJ, Pow-Sang JM, Gilbert SM, Poch MA. Change in Management Based on Pathologic Second Opinion Among Bladder Cancer Patients Presenting to a Comprehensive Cancer Center: Implications for Clinical Practice. Urology. 2016;93:130-4.

13. Al-Ibraheemi A, Folpe AL. Voluntary second opinions in pediatric bone and $\mathrm{ft}$ tissue pathology: a retrospective review of 1601 cases from a single mesenchymal tumor consultation service. Int J Surg Pathol. 2016:24:685-91.

14. Gordetsky J, Collingwood R, Lai WS, Del Carmen Rodriquez Pena M, RaisBahrami S. Second Opinion Expert Pathology Review in Bladder Cancer: Implications for Patient Care. Int J Surg Pathol. 2018;26:12-7.

15. Garcia D, Spruill LS, Irshad A, Wood J, Kepecs D, Klauber-DeMore N. The value of a second opinion for breast Cancer patients referred to a National
Cancer Institute (NCl)-designated Cancer center with a multidisciplinary breast tumor board. Ann Surg Oncol. 2018t:25:2953-7.

16. Rozenberg A, Kenneally BE, Abraham JA, Lenza M, Buchbinder R, Staples MP, Dos Santos OFP, Brandt RA, Lottenberg CL, Cendoroglo M, Ferretti M. Second opinion for degenerative spinal conditions: an option or a necessity? A prospective observational study. BMC Musculoskelet Diord. 2017; 18:354.

17. Corrias G, Huicochea Castellanos S, Merkow R, Langan R, Balachandran V, Ragucci M, Carollo G, Mancini M, Saba L, Mannelli L. Does second reader opinion affect patient Management in Pancreatic Ductal Adenocarcinoma? Acad Radiol. 2018:25:825-32.

18. Axon A, Hassan M, Niv Y, Beglinger C, Rokkas T. Ethical and legal implications in seeking and providing a second medical opinion. Dig Dis. 2008;26:11-7.

19. ANA T, Yang Q, Nelson HD, Longton G, Soneji SS, Pepe M, Geller B, Carney PA, Onega T, Allison KH, Elmore JG, Weaver DL. Second opinion strategies in breast pathology: a decision analysis addressing over-treatment, undertreatment, and care costs. Breast Cancer Res Treat. 2018;167:195-203.

20. Ruetters D, Keinki C, Schroth S, Liebl P, Huebner J. Is there evidence for a better health care for cancer patients after a second opinion? A systematic review. J Cancer Res Clin Oncol. 2016;142:1521-8.

21. Shmueli L, Davidovitch N, Pliskin JS, Balicer RD, Hekselman I, Greenfield G. Seeking a second medical opinion: composition, reasons and perceived outcomes in Israel. Isr J Health Policy Res. 2017;6:67.

22. Hillen MA, Medendorp NM, Daams JG, Smets EMA. Patient-driven second opinions in oncology: a systematic review. Oncologist. 2017:22:1197-211.

23. Payne VL, Singh H, Meyer AN, Levy L, Harrison D, Graber ML. Patientinitiated second opinions: systematic review of characteristics and impact on diagnosis, treatment, and satisfaction. Mayo Clin Proc. 2014;89:687-96.

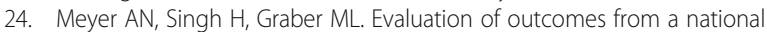
patient-initiated second-opinion program. Am J Med. 2015;128:1138.e25-33.

25. Mordechai O, Tamir S, Weyl-Ben-Arush M. Seeking a second opinion in pediatric oncology. Pediatr Hematol Oncol. 2015:32:284-9.

26. Shmueli L, Shmueli E, Pliskin JS, Balicer RD, Davidovitch N, Hekselman I, Greenfield G. Second medical opinion: utilization rates and characteristics of seekers in a general population. Med Care. 2016;54:921-8.

27. Gross SE, Hillen MA, Pfaff H, Scholten N. Second opinion in medical encounters - a study among breast cancer patients. Patient Educ Couns. 2017:100:1990-5.

28. Levy BR, Slade MD, Chang ES, Kannoth S, Wang SY. Ageism amplifies cost and prevalence of health Conditions. The Gerontologist. 2018;20:1-8.

29. Rask S, Elo IT, Koskinen S, Eero L, Koponen P, Castaneda AE. The association between discrimination and health: findings on Russian, Somali and Kurdish origin populations in Finland. Eur J Pub Health. 2018;28:898-0.

30. Antonovsky A. Social class, life expectancy, and overall mortality. Milbank Memorial Quarterly. 1967:45:31-73.

31. Rauch B. Socioeconomic status: a powerful but still neglected modulator of cardiovascular risk. Eur J Prev Cardiol. 2018;25:981-4.

32. Peier-Ruser KS, von Greyerz S. Why do Cancer patients have difficulties evaluating the need for a second opinion and What Is Needed to Lower the Barrier? A Qualitative Study. Oncol Res Treat. 2018;41:769-73.

33. Goldman RE, Sullivan A, Back AL, Alexander SC, Matsuyama RK, Lee SJ. Patients' reflections on communication in the second-opinion hematologyoncology consultation. Patient Educ Couns. 2009;76:44-50.

Ready to submit your research? Choose BMC and benefit from:

- fast, convenient online submission

- thorough peer review by experienced researchers in your field

- rapid publication on acceptance

- support for research data, including large and complex data types

- gold Open Access which fosters wider collaboration and increased citations

- maximum visibility for your research: over $100 \mathrm{M}$ website views per year

At BMC, research is always in progress.

Learn more biomedcentral.com/submission 